\title{
Age determination in subadults using histological analysis of bones
}

\section{Determinación de la edad en subadultos usando análisis histológico de los huesos}

\author{
Alba-R Valencia-V'ㄹ Javier Esquivias ${ }^{2}$; Miguel Botella²; Iván-A Trujillo-A ${ }^{1}$ \\ Suggested citation: Valencia AR, Esquivias J, Botella M, Trujillo IA. Age determination in subadults using histological analysus \\ of bones. Salud UIS. 2020; 52(4): 368-373. doi: https://doi.org/10.18273/revsal.v52n4-2020003 @) (1)
}

\begin{abstract}
Introduction: According to the literature, the amount of osteons has been suggested as a good proxy to determine the age of death in adults. However in subadults research has not been carried out yet. Objective: To determine the accuracy of the histomorphometric technique predicting the age at death in subadults using bone remains. Methodology: The information of static histomorphometric parameters from about 120 iliac bones retrieved from the exhumed remains of subadults whose age at death was known was taken from the Granada collection. In order to predict the age at death we performed a step by step linear regression to estimate the fittest model. Results: The most closely and significantly associated biopsy findings with age were: internal and external number of secondary osteons and the trabecular bone volume. Pearson's correlation index indicated a weak linear association among these variables. To assess the accuracy of the model we used a coefficient of determination with a 0.32 value. $32 \%$ of the age variation in the subadults was explained by the three variables. Conclusion: this regression model explains a percentage of the total age variation in the subadult population. However this model is not enough to determine the age at death.
\end{abstract}

Keywords: Age determination by skeleton; Ilium; Harvesian system; Osteon; Least-Squares analysis.

\section{Resumen}

Introducción: la capacidad de predicción de las osteonas para determinar la edad de muerte de los individuos ha sido descrito en la literatura científica. No obstante, no se ha determinado dicha capacidad en individuos subadultos. Objetivo: determinar la eficacia de lo parámetros histomorfometricos en población subadulta. Metodología: se realizaron biopsias de hueso ilíaco en los restos de 120 subadultos, de la Colección Osteológica de Granada, con edad conocida en el momento de la muerte. Para establecer la capacidad de predicción se utilizó el R2 obtenido a partir de regresión lineal múltiple. Resultados: las variables con mayor nivel predictivo y significativo para la estimación de la edad fueron: recuento de osteonas tipo 2 de la cortical interna y externa, y el volumen óseo trabecular; En la evaluación del modelo, se obtuvo un coeficiente de determinación de 0.32 , es decir, el $32 \%$ de la variación en la edad de los subadultos se explica por el modelo. Sin embargo, se evidenció diferencias en la capacidad de predicción por sexo. Conclusión: este modelo de regresión explica un porcentaje sustancial de la varianza de la edad de los individuos en la muestra. No obstante, no es suficiente para garantizar una adecuada predicción de la edad al momento de muerte de los individuos subdultos.

Palabras clave: Determinación de la edad por el esqueleto; Modelos líneales; Histología; Osteona.

1. Universidad Surcolombiana. Neiva, Colombia

2. Universidad de Granada. Granada, España

Correspondence: Alba Rocio Valencia Valderrama. Address: calle 9 14-03. Phone number: +57 316 8206493. Email: albarocio.valencia@usco. edu.co 


\section{Introduction}

Physical and forensic anthropologists are frequently faced with the challenge of identifying bone remains and determining their age and sex, among other characteristics, using morphological and metric techniques. Methods used to determine the age of infants and adolescents include analyses of the cranium, ossification centers, tooth eruption, epiphyseal closure, and both long bone and spinal column lengths; Working with relative precision thanks to the moderately constant rate of growth in young individuals.

The main drawback for macroscopic techniques is the need of a complete skeleton due to their lower reliability in fragmented or incomplete remains, for which histological age estimation techniques are considered more useful ${ }^{1}$.

Bone histology has been used in age estimation since 1965, when Kerley² first proposed the study of bone microstructure for this purpose. Different methods developed so far have varied the type of bone used, the anatomic site from which it is sampled, the amount of bone tissue required, and the microscopic structures examined. Potential limitations of this technique include variations in age profile, nutritional conditions, and cause of death ${ }^{3}$; age estimations based on bone microstructure have proven relatively accurate in populations from North America, South America, and Europe since reference collections are included.

In adults, age estimation by histology is generally based on remodeling evidence, given the association between age and osteon accumulation ${ }^{4}$. However, bone histomorphology is more complex in subadults than in adults. Although remodeling begins very early during prenatal life $^{5}$, the influence of cortical bone growth and remodeling is subsequently masked during infancy. Consequently, the accumulation of osteons is only weakly correlated with age before the second decade of life ${ }^{6}$.

Streeter ${ }^{7}$ performed a histological study of 72 subadult ribs from individuals aged between 2 and 21 years and reported systematic changes in the microstructure of their rib cortex as a background to age determination. Agnew $^{8}$ tested this method in subadult ribs from the $11^{\text {th }}-12^{\text {th }}$ century in a Polish cemetery and found major differences in the growth and development of this bone between medieval and contemporary populations.

\section{Methodology}

The static histomorphometric parameter information from about 120 iliac bones retrieved from exhumed remains of subadults with a known age of death was taken from the Granada collection, ${ }^{9}$ of which 72 are males and 48 females with a range of age between 1 and 1800 days. Samples of iliac bone were gathered and prepared for microscopic examination following the protocol proposed by Valencia, et al. ${ }^{10}$ A Nikon microscope (Model Eclipse E200) equipped with a Nikon digital camera (Model Coolpix S10) was used to take digital images at 4X, 20X, and 40X magnifications. The images were edited with the Microsoft Paint program and ImageTool 3.0 UTHSCSA software was used for their analysis (image 1). Structural parameters, including cortical width and trabecular volume (TV) were determined from reconstructed images of the complete biopsy at $4 \mathrm{X}$ magnification (Figure 2). All images analyses were carried out by a pathologist.

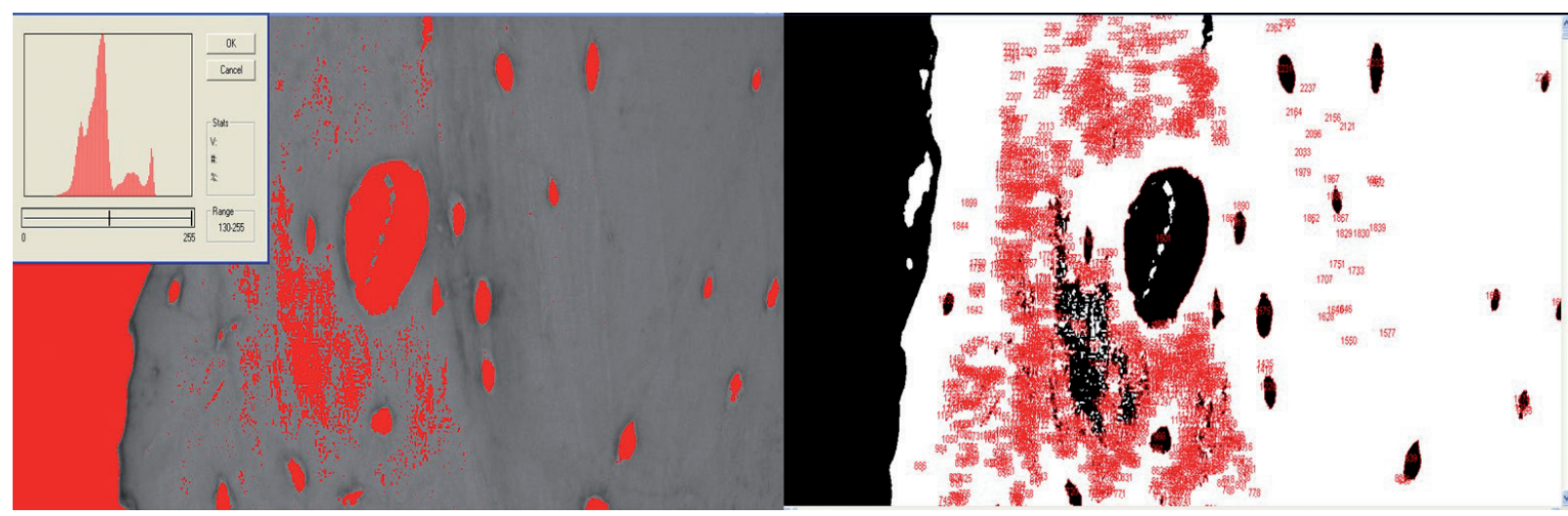

Figure 1. Harvesian canal and osteons photograph visualized with UTHSCSA. IMAGE TOOL version 3.0. 


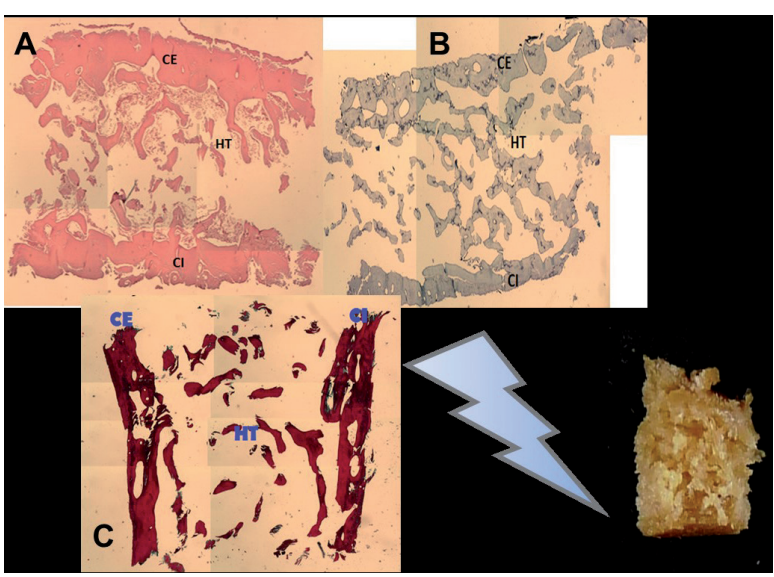

Figure 2. In the bottom right biopsy bone is observed. In panel A) there is a compact and trabecular bone slice dyed using $\mathrm{H}-\mathrm{E}$, in panel $\mathrm{B}$ the bone is dyed using toluidine blue, in panel C) the bone is dyed using Masson trichromico.

Images to 20X magnification were used to determine the total count and the type of osteons in the inner and outer cortex. Likewise, 40X images were used to record the measurements taken from the Haversian canals area, perimeter, major longitudinal axis, minor longitudinal axis, elongation, roundness, feret diameter, and compactness.

For a higher prediction level, we estimated a step by step multiple linear regression, keeping in the model those variables that had a statistical significant level. $\mathrm{P}$ values lesser to $<0.05$ were considered significant in all tests. The followings models were used to explore the relation between the variables:

$$
\begin{aligned}
& \ln \left(y_{i}\right)=\beta_{0}+\ln (T V)+\Sigma \beta_{j i} x_{j i} \\
& \ln \left(y_{i}\right)=\beta_{0}+\ln (T V)+\Sigma \beta_{j i} \ln \left(x_{j i}\right)
\end{aligned}
$$

Where $y_{i}$ is the age at death of the $i$ person, $T V$ is trabecular volume, $x_{j i}$ where $j$ is the variable for the person $i$. These variables include all measures of
Havers canal, and the amount of type one and type two osteons. The logarithmic form was the best suited one for the monotonic transformation into a linear relationship among variables.

\section{Results}

According to Table 1, the value of median age (p50) is 90 months, the major part of individuals were males $(60 \%)$, on the contrary only $40 \%$ percent are females.

In the sample the amount of secondary osteons is higher in the external cortex than in the internal cortex. Furthermore, the 50-th percentile of the sample got 27,5 $\mu \mathrm{m}$ of trabecular Volume.

Table 1. Histological characteristics, age and sex.

\begin{tabular}{lcc}
\hline \multicolumn{1}{c}{ Factor } & Level & Value \\
\hline $\mathrm{N}$ & & 120 \\
Age, mean (SD) & & $318.675(477.60)$ \\
Sex & Female & $48(40.0 \%)$ \\
& Male & $72(60.0 \%)$ \\
$\begin{array}{l}\text { Trabecular bone } \\
\text { volume, median (IQR) }\end{array}$ & & \\
$\begin{array}{l}\text { Number of secondary } \\
\text { internal osteons, } \\
\text { median (IQR) }\end{array}$ & $18(11,29)$ \\
$\begin{array}{l}\text { Number of secondary } \\
\text { external osteons, } \\
\text { median (IQR) }\end{array}$ & \\
\hline
\end{tabular}

According to the following table 2, none of the variables considered show significant differences by sex. Although, the female median age is higher than the male one, this was not a significant difference. We decided to perform the linear regressions to both sexes, due to reported differences and possible effects of biological features.

Table 2. Histological characteristics and age by sex.

\begin{tabular}{lcrr}
\multicolumn{1}{c}{ Factor } & Female & Male & p-value \\
$\mathrm{N}$ & 48 & 72 & 0.25 \\
Age, median (IQR) & $120(30.5,690)$ & $90(19.5,285)$ & 0.38 \\
$\begin{array}{l}\text { Trabecular bone volume, median (IQR) } \\
\text { Number of secondary internal osteons, }\end{array}$ & $26.096068(21.502633,33.719491)$ & $28.460819(22.36354,37.528755)$ \\
median (IQR) & $21(10.5,30)$ & $17(11,24)$ & 0.30 \\
$\begin{array}{l}\text { Number of secondary external osteons, } \\
\text { median (IQR) }\end{array}$ & & $9.5(6.5,14)$ & 0.47
\end{tabular}


Table 3. Prediction models using linear regression.

\begin{tabular}{|c|c|c|c|c|c|c|}
\hline & $\begin{array}{c}(1) \\
\text { General }\end{array}$ & & $\begin{array}{c}(2) \\
\text { Male }\end{array}$ & & $\begin{array}{c}(3) \\
\text { Female }\end{array}$ & \\
\hline Ln(Trabecular bone volume) & $-1.692^{* * *}$ & $(-4.31)$ & $-1.930^{* * *}$ & $(-3.49)$ & $-1.307^{*}$ & $(-2.31)$ \\
\hline Number of secondary internal osteons & $-0.0337^{* *}$ & $(-2.78)$ & $-0.0360^{*}$ & $(-2.37)$ & -0.0276 & $(-1.30)$ \\
\hline Number of secondary external osteons & $-0.0465^{*}$ & $(-2.26)$ & -0.0233 & $(-0.78)$ & $-0.0751^{*}$ & $(-2.38)$ \\
\hline _cons & $11.37^{* * *}$ & $(8.79)$ & $11.77^{* * *}$ & $(6.36)$ & $10.61^{* * *}$ & $(5.86)$ \\
\hline $\mathrm{N}$ & 120 & & 72 & & 48 & \\
\hline$R^{2}$ & 0.321 & & 0.250 & & 0.454 & \\
\hline
\end{tabular}

$t$ statistics in parentheses

${ }^{*} p<0.05,{ }^{* *} p<0.01,{ }^{* * *} p<0.001$

The table 3 shows the variables that remained significant $(p<0.05)$ in the step by step of the general estimations and after estimations were performed by sexes. It should be noted that in both sexes, the trabecular volume remained a significant variable and with the higher level of incidence in the variance of age of death in the sample. The number of secondary osteons changed its significance according to the sex: for the external model the amount was significant for women whereas for the internal model it was significant for men.

In this model, the intercept plays an important role, since all variables are negatively associated with the age, thus as logarithmic measures of the trabecular volume and the number of osteons increased, the estimated age of subadults in the sample decreased. In general terms, the model explains 32 percent of the differences in the ages; however, this percentage is higher in women than men.

\section{Discussion}

The age estimation method for subadults proposed in this study is based on the life-long process of bone remodeling, resulting in a correlation between the number of osteons and age that represents the main basis of histological age estimation methods. The original components of compact bone (e.g., circumferential lamellar bone and primary osteons) are gradually replaced by new structures over the years. The remodeling process continues into old age, at the expense not only of laminar bone and primary osteons but also of secondary osteons, which form osteon fragments. For this reason, most histological age estimation methods use the number of osteons and osteon fragments as a key variable ${ }^{11}$.

In the present study of subadults, a significant reduction in TV was observed in higher ages, in agreement with previous reports and attributed to remodeling 371 processes $^{12}$. Analyses of the iliac crest in healthy male and female adults found a marked reduction in TV and a decrease in the amount of trabecular bone deposited by basic multicellular units as the individual grows old $^{13}$. Accordingly, bone formation is always preceded by bone resorption at the same localization during bone remodeling.

Thompson ${ }^{4}$ observed a constant degradation of the cortical width, with a reduction in bone mineral density starting at the age of 50 and these findings were confirmed in a subsequent study of individuals aged $17-8^{14}$.

Histological age estimation methods generally consider the total number of osteons, which are the structural and functional units of bone tissue. Although most authors have found that their number increases throughout life $\mathrm{e}^{2,15,16}$, the total osteon count was negatively correlated with age in the present study, i.e., a higher osteon count was associated with younger age. This discrepancy may be attributable to differences in the sampling site, in the presence of malnutrition, diseases, bone tissue damage, and/or in the subjective evaluations of researchers.

Baltadjiev $^{5}$ studied 150 human tibias at six, seven, eight, and nine months of gestation. Bones in the ninth month of gestation were formed by osteons with multiple layers and narrow Haversian canals that were fewer than in previous months, proving that differences in the bone tissue between the middle and end of pregnancy were statistically significant. Fewer primary $(0.40)$ than secondary (11.83) osteons were observed in the current subadult bone samples. This result is consistent with the findings by Kerley ${ }^{2}$ that primary osteons present in the femur, tibia, and fibula decrease during adolescence and disappear at around the age of 55 years, while secondary osteons progressively increase until the age of around 
95 years. Singh, et al. ${ }^{17}$ also found a positive correlation between secondary osteon count and higher age in jaw, femur, and tibia samples.

Ericksen ${ }^{17}$ studied 328 individuals and developed a method to estimate the age at death based on five microstructural variables and three main values, including secondary and primary osteon counts, reporting their highly significant correlation with age. Watanabe, et al. ${ }^{18}$ researched using measurements such as area, perimeter, maximum and minimum diameter of osteons, the number of Haversian canals and secondary and fragmentary osteons of femurs from 98 Japanese children and adults, finding that osteon counts were highly correlated with age but not with the number of Haversian canals. A very low correlation with age was also observed for the data on Haversian canals in the present study, and they were not included in the predictive model.

Ericksen ${ }^{17}$ and Ahlqvist, et al. ${ }^{15}$ found that specific equations by sex, showed better results that nonspecific equations. These results differ with Kerley², who did not found sex differences. Singh, et al. ${ }^{16}$ developed equations for men with accurate predictions, but to predict the age at death in women, it is necessary to calculate estimations by sexes, all former results are in line with the ones found with the estimations by Thompson ${ }^{4,15}$.

This study explored the usefulness of histomorphometry technique to estimate the age at death of subadults, for whom conventional estimation methods are generally inadequate. Most available histological age estimation methods have been developed in populations with very few or no subadult individuals, and are therefore, not applicable in these younger age groups. The histological variables with greatest discrimination capacity were the total amount of secondary osteons in the internal and external cortical and trabecular volume, but this is not adequate enough to predict the age at the moment of death in subadults accurately.

\section{Acknowledgments}

The authors are grateful to Dr. Inmaculada Alemán, Director of the Granada Osteological Collection and to the staff of the Department of Surgery (Experimental Surgery Laboratory) and the Department of Pathology of the School of Medicine of the University of Granada (Spain) for their collaboration in the study.

\section{Conflict of interest}

The authors declare that there was not conflict of interest.

\section{References}

1. Stout SD, Dietze, WH, Işcan MY, Loth SR. Estimation of age at death using cortical histomorphometry of the sternal end of the fourth rib. J Forensic Sci. 1994; 39(3): 778-784.

2. Kerley ER. The microscopic determination of age in human bone. Am J Phys Anthropol. 1965; 23(2): 149-163. doi: 10.1002/ajpa.1330230215

3. Aiello LC, Molleson T. Are microscopic ageing techniques more accurate than macroscopic ageing techniques? J Archaeol Sci. 1993; 20(6): 689-704. doi: https://doi.org/10.1006/jasc.1993.1043

4. Thompson DD. The core technique in the determination of age at death of skeletons. J Forensic Sci. 1979; 24(4): 902-915.

5. Baltadjiev G. Micromorphometric characteristics of osteons in compact bone of growing tibiae of human fetuses. Cells Tissues Organs. 1995; 154(3):181185. doi: 10.1159 / 000147767

6. Streeter M. A Four-stage method of age at death estimation for use in the subadult Rib Cortex. J Forensic Sci. 2010; 55(4): 1019-1024. doi: 10.1111/j.1556-4029.2010.01396.x

7. Streeter M. Histomorphometric characteristics of the subadult rib cortex: Normal patterns of dynamic bone modeling and remodeling during * growth and development. University of Misouri-Columbia; 2005.

8. Agnew A. Histomorphological aging of subadults: a test of streeter's method on a medieval archaeological population. Ohio State University; 2006.

9. Alemán I, Irurita J, Valencia AR, Martínez A, LópezLázaro $\mathrm{S}$, Viciano $\mathrm{J}$, et al. Brief communication: the Granada osteological collection of identified infants and young children. Am J Phys Anthropol. 2012;149(4): 606-610. doi: 10.1002/ajpa.22165

10. Valencia AR, Esquevias J. Técnica histológica en huesos de subadultos como posible predictor de edad. Propuesta de protocolo. Universidad de Granada, Granada, España; 2009.

11. Crowder C, Stout S, Stout S. Bone histology an antropology perspective. 1 ed. CRC Press; 2011.

12. Compston JE, Mellish RWE, Garrahan NJ. Age-related changes in iliac crest trabecular microanatomic bone structure in man. Bone. 1987; 8(5): 289-292. doi: https://doi.org/10.1016/87563282(87)90004-4 
13. Rauch F, Travers R, Parfitt AM, Glorieux FH. Static and dynamic bone histomorphometry in children with osteogenesis imperfecta. Bone. 2000; 26(6): 581-589. doi: 10.1016/s8756-3282(00)00269-6

14. Thompson DD. Microscopic determination of age at death in an autopsy series. J Forensic Sci. 1981; 26(3): 470-475.

15. Ahlqvist J, Damsten O. A modification of Kerley's method for the microscopic determination of age in human bone. J Forensic Sci. 1969; 14(2): 205-212.

16. Singh IJ, Gunberg DL. Estimation of age at death in human males from quantitative histology of bone fragments. Am J Phys Anthropol. 1970; 33(3): 373381. doi: 10.1002/ajpa.1330330311

17. Ericksen MF. Histologic estimation of age at death using the anterior cortex of the femur. Am J Phys Anthropol. 1991; 84(2): 171-179. doi: 10.1002/ ajpa.1330840207

18. Watanabe Y, Konishi M, Shimada M, Ohara H, Iwamoto S. Estimation of age from the femur of Japanese cadavers. Forensic Sci Int. 1998;98 (1-2): 55-65. doi: 10.1016/s0379-0738(98)00136-4 